\title{
9 \\ Differentiated Citizenship: A Liberal Politics of Potential
}

\section{Introduction}

This chapter discusses differentiated liberal citizenship. It shows the constraints on power that arise when an indigenous people reject differentiated liberal citizenship, as occurred in New Zealand when the Iwi Chairs Forum's Independent Working Group on Constitutional Transformation, Matike Mai Aotearoa (2016), recommended a constitutional order based on rigid distinctions between Maori and Crown authority. The working group's report, He whakairo here whakaumu mo Aotearoa, made the distinction by positioning the New Zealand Crown as an exclusively Pakeha entity, thereby making it the site of just some citizen's political authority (O'Sullivan, 2007).

This chapter presents the case for a more inclusive commonwealth to allow Maori to exercise liberal citizenship of the state as an essential complement to the political authority that iwi may exercise. Through a series of examples in which differentiated liberal citizenship has in fact been applied in New Zealand and other jurisdictions, this chapter highlights its potential as a path to self-determination. It also shows how measures such as guaranteed parliamentary representation, a 'voice to parliament' in Australia and democratic participatory parity at all levels of the state political system are important constituents of the right to self-determination. As the Declaration affirms: 
Indigenous peoples have the right to determine their own identity or membership in accordance with their customs and traditions. This does not impair the right of indigenous individuals to obtain citizenship of the States in which they live. (UN, 2007b, art. 32)

It is important to attend to not only the constitutional or legal aspects of the right to self-determination but also the political. Constitutions may set the rules, but politics is the process through which self-determination's practical meanings are worked out with others. Consequently, this chapter is especially concerned with political transformation; in particular, the ways in which political systems might work to include indigenous people, epistemologies and values in the policy process. This requires an indigenised bureaucracy and policy processes - that is, an indigenous voice and presence wherever policy is made.

In these ways, the idea of an indivisible and absolute Crown sovereignty is challenged. Public authority becomes the property of the sovereign citizenry of which indigenous peoples are a part, just as much as they are a part of their own nations or iwi. In New Zealand, as this chapter explains, this means that the Crown cannot be presented as the repository of Pakeha authority alone.

The chapter shows that departing from a bicultural binary in favour of differentiated liberal citizenship creates more expansive opportunities for political influence and greater opportunities for self-determination as a meaningful practice that may improve people's lives. The connection between citizenship and self-determination is especially strong when there is public policy space for indigenous peoples to manage public services for themselves and in their own ways. The chapter presents ACCHOs, introduced in Chapter 5, as an example and proposes ways of strengthening this model of self-determination-not so much through the redistribution of resources but through the redistribution of power. Inequitable health outcomes reflect more than just the failings of egalitarian justice. This is because health outcomes, like outcomes in education and employment for example, are reflections of people's capacities of citizenship.

The political will to change the nature of citizenship by allowing it to be exercised differentially is weak across most jurisdictions, many of which are struggling to come to terms with the politics of indigeneity that the Declaration imagines and strengthens. As this chapter discusses, with reference to Canada, strengthening capacities for self-determination may also call for a deliberate focus on the reconciliation of interests and not 
simply the reconciliation of conflict. Recognising difference is important, but difference ought not blind the policy process to overlapping interests that may become more obvious in political systems in which decisions are made according to processes of reasoned deliberation. In other words, equal political capacity means active citizenship, which in turn is the practice of self-determination.

\section{He Whakairo Here Whakaumu mō Aotearoa}

In 2016, the New Zealand Iwi Chairs Forum's Independent Working Group on Constitutional Transformation, Matike Mai Aotearoa, published a report on how New Zealand's constitutional arrangements might be transformed to entrench a bicultural form of government. The report sought stronger political relationships between iwi and the Crown, and restoration of the sovereignty that was, according to the Waitangi Tribunal ('He Whakaputanga me te Tiriti', 2014), usurped, not ceded. The report's purpose was to foster 'constitutional transformation'.

According to Jones (2014), Maori constitutionalism proceeds from:

1. Whanaungatanga - 'the centrality of relationships to Maori life';

2. Manaakitanga (and kaitiakitanga) - 'nurturing relationships, looking after people, and being very careful how others are treated ...;

3. Mana - 'the importance of spiritually sanctioned authority and the limits on Māori leadership';

4. Tapu/Noa - 'respect for the spiritual character of all things';

5. Utu - 'the principle of balance and reciprocity'. (p. 191)

Importantly, these precepts do not require the Crown and Maori to be treated as rigidly distinct entities, with the Crown's affairs a matter for 'them' not 'us' in an unproblematic bicultural binary. Instead, they can be understood as examples of the values that Maori citizens might bring to their participation in public affairs that might 'indigenise' the policy process, as discussed later in this chapter.

Extensive consultations preceded He whakairo here whakaumu. These were among the most comprehensive and considered constitutional discussions in recent New Zealand history. However, constitutions are restraining 
just as they are emancipatory. The goals of Maori self-determination are realisable only through political transformation. Constitutional transformation may support political goals, but it does not guarantee them. An agreeable constitution, especially in a state that does not have a single written instrument, is not an end in itself. To provide scope for political transformation beyond that which already exists, a constitution would need to have greater force than the combined influence of the Treaty of Waitangi, common law and international legal instruments such as the Declaration. Ultimately, and simply, political transformations require political voice wherever power is exercised, not only within the Maori sphere of He whakairo here whakaumu's bicultural world.

Biculturalism views Maori and non-Maori populations 'as if they [run] on separate parallel train tracks' (Chapple, 2000, p. 7). The distinct non-Maori ethnicity that it ascribes to the Crown leaves the Crown to make decisions for 'its people' (Matike Mai Aotearoa, 2016, p. 9)—a distinct, easily identifiable and homogenous people in whose affairs Maori have no business.

Maori may enjoy the right, in principle, to distinct separation from biculturalism's Pakeha Crown. However, self-determination embodies greater political authority when sovereignty is recognised as the concern of relative and relational distributions of power. The proposition that some authority belongs to 'us' (i.e. Maori) and some to 'them' (i.e. Pakeha) is a common theme in Maori political rhetoric. However, the theme is inconsistent with Maori political practice, especially the considered Maori pursuit of parliamentary membership from general and party list seats as well as from the guaranteed Maori constituencies.

Maori unapologetically and systemically pursue participation in the executive. Since the 1970s, it has been extremely rare for Cabinets not to include Maori ministers. He whakairo here whakaumu understated the essential role that Maori members of parliament play in advancing opportunities for self-determination. Rather than acknowledge this inclusive model of Maori participation in the executive and legislature, the report proposed six alternative structural models to distinguish Maori political authority from that of the Crown-in-Parliament:

1. A tricameral or three sphere model consisting of an Iwi/Hapū assembly (the rangatiratanga sphere), the Crown in Parliament (the kāwanatanga sphere) and a joint deliberative body (the relational sphere). 
2. A different three sphere model consisting of an assembly made up of Iwi, Hapū and other representation including Urban Māori Authorities (the rangatiratanga sphere), the Crown in Parliament (the kāwanatanga sphere), and a joint deliberative body (the relational sphere).

3. A further three sphere model consisting of an Iwi/Hapū assembly (the rangatiratanga sphere), the Crown in Parliament (the kāwanatanga sphere), and regional assemblies made up of Iwi, Hapū and Crown representatives (the relational sphere).

4. A multi-sphere model consisting of an assembly of Iwi/Hapù and other Māori representation (the rangatiratanga sphere) and the Crown in Parliament (the kāwanatanga sphere). It also includes a relational sphere which would have two parts a constitutionally mandated set of direct Iwi/Hapū/Crown relationships to enable direct Iwi/Hapu-Crown decisionmaking plus a unitary perhaps annual assembly of broader Māori and Crown representation.

5. A unicameral or one sphere model consisting of Iwi/Hapū and the Crown making decisions together in a constitutionally mandated assembly. This model does not have rangatiratanga or kāwanatanga spheres. It only has the relational sphere.

6. A Bicameral Model made up of an Iwi/Hapū assembly and the Crown in Parliament. This model has distinct rangatiratanga and kāwanatanga spheres but has no provision for a relational sphere. (Matike Mai Aotearoa, 2016, p. 10)

The first four of these models, and the sixth, diminish Maori political authority in ways that prevent self-determination within the state. The fifth is essentially the current national parliament with some strengthening of Maori representation. However, in making no provision for rangatiratanga (chiefly authority), it became the first serious Maori proposal since 1840 to set aside the Treaty of Waitangi. Were it amended to include rangatiratanga, it would be the only model consistent with differentiated liberal citizenship and the meaningful sharing of sovereignty.

He whakairo here whakaumu's models were intended to constrain Crown sovereignty. However, and by contrast, self-determination contests Crown sovereignty's exclusive form; it contests the very idea that public sovereignty is not shared by Maori. The report does not consider what it means for a Maori person to be a citizen of a liberal democratic state. It makes passing references to citizenship's limits but does not consider its possibilities. For Maori to separate themselves from the 'Crown's people' is 
a radical political and constitutional proposal that would logically exclude Maori from membership of the New Zealand Parliament and from the right to vote for members of parliament.

A more productive approach would be for the 'relational sphere'-in which Maori and other citizens 'make decisions together'-to remain the national parliament, accompanied by the strengthening of Maori participation in other spheres of influence in which sovereign power is dispersed. Guaranteed participation at every level of the political system allows indigenous people to pursue their distinctive aspirations and to engage in public affairs as members of the sovereign citizenry rather than as subjects waiting for others to conceptualise the justice that ought to be 'done' to them.

He whakairo here whakaumu sought the restoration of mana, which:

as a political and constitutional power ... denotes an absolute authority. It was absolute because it was absolutely the prerogative of every polity, but it was also absolute in the sense that it was commensurate with independence and an exercise of authority that could not be tampered with by any other polity. (Matike Mai Aotearoa, 2016, p. 34)

This perspective of mana positions sovereignty in absolute and indivisible terms, yet modern sovereignty is undeniably dispersed. Sovereign political authority does not reside with one being or institution alone; it is relative, relational and shared. This is because the sovereign citizenry is not a singular being. Mana is shaped by external influences, with colonialism a transgression of mana. Moral objection alone cannot prevent that transgression. Mana's protection through constitutional arrangements is possible only through politics, which is why full attention to political context is preliminary to self-determination. As one participant in the He whakairo here whakaumu discussions observed:

Although times have changed those old tikanga remain ... we never lost or ceded our mana and never forgot what was tika [right] about how we should exercise it. The challenge now is to adapt those things in the 21st century. (Matike Mai Aotearoa, 2016, p. 36)

The idea that the body of authority that is not exclusively Maori belongs to a Leviathan-like Crown prevents Maori from fully exploring political possibilities and makes substantive justice unachievable. Power is 
continuously rebalanced by demographic changes and by changes in people's perceptions of what is just and pragmatic. Indeed, as a He whakairo here whakaumu participant remarked:

Sometimes we get caught in the trap of just accepting what colonisation has done, like setting up its own government, and saying that it's right or it can't be changed because it's too hard ... we should try because that's what the treaty talked about. (Matike Mai Aotearoa, 2016, p. 37)

Maori make claims against the Crown for breaches of the Treaty of Waitangi. In this sense, they are binary opponents. However, to see Maori and Pakeha persons as apart in the politics of citizenship is limiting.

If people do not simply wish 'to talk about structures but rather the ideals that might transform how their right to make their own decisions is perceived' (Matike Mai Aotearoa, 2016, p. 38), it may be useful to consider how their right to citizenship is perceived, protected and advanced. While He whakairo here whakaumu rightly distinguishes rangatiratanga from käwanatanga (governorship) as spheres of political influence, Maori need not surrender one for the other. Participation in rangatiratanga is an ancestral right. Participation in citizenship is a treaty right and a liberal right and the Declaration upholds both forms of political authority.

The notion of 'subjecthood' as it was understood in 1840 and extended to Maori under Article 3 of the Treaty of Waitangi has evolved into a more far-reaching and politically meaningful citizenship. He whakairo here whakaumu provides a clear account of rangatiratanga, but käwanatanga is left as something belonging to others. However, if Maori are not active participants in kawwanatanga - the domain of the liberal citizen - they are confined to subjecthood.

The ascription of a non-Maori ethnic character to the Crown prevents consideration of the relationship between rangatiratanga and käwanatanga in a liberal democratic state- a political structure that is very different from a Crown reigning over its subjects. Liberal democratic citizenship may constrain self-determination but not in the same ways or for the same reasons as subjecthood. The constitutional and political context of 1840 does not provide a lens through which the limits and possibilities for Maori autonomy can presently be considered. It does not explain how kāwanatanga, especially, might support self-determination. 
He whakairo here whakaumu makes no comment on how or by what authority the state bureaucracy ought to function. Nor does it provide any path for Maori appointments to the executive. The report reflects a significant dissonance between constitutional thought and political practice. Contemporary politics is pragmatic rather than theoretical and influenced by immediate political possibilities, economic imperatives and treaty settlements. Contemporary Maori politics reflect differentiated liberal citizenship's possibilities. Moreover, it provides a foundation for extending Maori influence both within and beyond the state, and for recognising that opportunities for self-determination are greatest when rangatiratanga and käwanatanga are accepted as sites of legitimate Maori political authority.

Given He whakairo here whakaumu's perspective on the validity of an absolute and easily distinguishable Maori-Pakeha binary, it might be assumed that workshop participants were people of singular Maori identity. If so, their perspectives are likely to be more fixed than the 53.5 per cent of Maori who claim two or more ethnic identities (Statistics New Zealand, 2013). The report's models require people of Maori descent to take a singular identity: Maori or Pakeha. Imposing a choice of this kind would be culturally and socially problematic for a people inclined to place significant value on whakapapa (ancestry) from wherever it comes. The views of Maori who claim additional non-Maori, non-Pakeha ancestries may further complicate the report's simple view of the relationship between ethnicity and political arrangements.

Although He whakairo here whakaumu represents a significant body of Maori political thought, it is difficult to imagine Maori being satisfied with structural separation from the state. Maori have always wanted to sit in the executive, parliament and judiciary. They surely want equal capacity to influence public sector policymaking, and those who participate in public life in these ways are not the state's junior bicultural partners but active participants in its structure, character and purpose. The Declaration does not imagine junior and senior partners because:

Indigenous peoples have the right to maintain and strengthen their distinct political, legal, economic, social and cultural institutions, while retaining their right to participate fully, if they so choose, in the political, economic, social and cultural life of the State. (UN, 2007b, art. 5) 
He whakairo here whakaumu presumes 'public reasonableness' (introduced in the previous chapter). For example, it requires a suspicious public to accept that legislation should be assessed for consistency with the Treaty of Waitangi in the first place. If public reasonableness establishes that consistency with the treaty is a shared value, there would still need to be public agreement that consistency be assessed through an especially established parliamentary chamber. As Bohman and Rehg (1997) explained:

a democracy based on public deliberation presupposes that citizens or their representatives can take counsel together about what laws and policies they ought to pursue as a commonwealth. And this in turn means that the plurality of competing interests is not the last word, or sole perspective, in deciding matters of public importance. The problem, to use Kant's terms is to bring about 'the public use of reason'. (p. x)

The Treaty of Waitangi means that the Crown will always remain integral to political discourse; however, the Crown is a concept that, in its current ordinary usage, raises significant obstacles to Maori capacity for self-determination through differentiated citizenship. Current ordinary usage means that the Crown is inevitably an instrument of bicultural exclusion rather than the expression of a political authority that all are entitled to share.

\section{Beyond Bicultural Exclusion}

The theoretical tension between the Crown as treaty partner and transgressor, and the Crown as the repository of all citizens' collective sovereignty, is an important one, yet its significance is not widely recognised in treaty scholarship nor in public discourse. He whakairo here whakaumu's conceptual weakness is its failure to consider this tension between the Maori citizen's dual membership of a hapu that signed the treaty and a sovereign national public from which the Crown derives its authority.

Beyond biculturalism, there may lie a commonwealth with distinct parts and united by equal moral capacities to determine how those parts are ruled. Commonwealth means sharing individual authority with a collective power from which protection is obtained. Commonwealths are based on trust, as Hobbes (1998) declared: 'Justice and Propriety 
Begin with the Constitution of Commonwealth. But ... Covenants of mutual trust, where there is a fear of non-performance on either part ... are invalid' (p. 424). For Hobbes:

The Essence of the Common-wealth is One person [or assembly]... by mutual Covenants one with another that made themselves every one the Author, to the end he may use the strengths and means of them all, as he shall think expedient, for their Peace and Common Defence. (p. 515)

Accepting membership of the common citizenry is preliminary to holding public institutions accountable for what they do and for the values that inform their actions. All people ought to take their place within the commonwealth - a body in which authority is always contested and never exclusive.

To bring indigenous politics from the margins to the mainstream, citizenship requires a commonwealth alongside a liberal theory of indigeneity. This means reconfiguring the ways in which Hobbes's understanding of sovereignty prevails as a justification for exclusion. For example, in New Zealand, the idea that rangatiratanga constrains sovereignty is important: it implies a distinction between the two. However, it may be that reconceptualising rangatiratanga as a legitimate part of the sovereign whole better reflects the political status that Maori are entitled to claim. Rangatiratanga then contributes to self-determination within the state; rather than constraining sovereignty, rangatiratanga helps to define it. In helping to define national sovereignty and sever biculturalism's exclusive association of the sovereign Crown with the Pakeha polity, rangatiratanga strengthens the possibilities for the Maori exercise of authority in and over their own affairs.

Rangatiratanga is diminished if it is not accepted into the sovereign whole. Its absence means that it is only from beyond the state (as bicultural partner) that scope exists for Maori to contribute to public policy. Separating rangatiratanga from sovereignty imposes a structural limit on self-determination and depends on a fiduciary obligation to Maori in place of the participatory parity of Maori citizens as equal shareholders in Crown sovereignty.

Self-determination cannot occur if the complementary relationship between differentiated citizenship's two spheres-the indigenous nation and the state-does not enjoy the space to develop. Indeed, as the Canadian Public Policy Forum (2017) argued: 
The outcome of true reconciliation must be to ensure that Indigenous peoples are fully accorded the opportunity to fully participate in the economic and social fabric of our country ... of the broader society-on corporate boards in business-school case studies, in executive roles, and union leadership, in associations, in government and in regulatory and environmental assessment bodies. (pp. 6-7)

First Nations people need to be part of the national middle class because that is where a disproportionate share of national sovereignty resides and where national wealth and decision-making capacity are found. They also need to be part of the 'sovereign' public. Poor education and low incomes compromise indigenous people's capacity as citizens, whereas increasing the size of the indigenous middle class raises capacity to engage as equals in the affairs of the nation-state.

Notwithstanding this book's objections to He whakairo here whakaumu, the report did identify 'a very real desire for a more open constitutionalism and what we describe as a conciliatory and consensual democracy rather than an adversarial and majoritarian one' (Matike Mai Aotearoa, 2016, p. 9). In this sense, the report is a most important and instructive document, as it shows the values that people wish to inform political engagement. These values are consistent with differentiated liberal citizenship and may, in fact, enjoy greater influential possibilities under liberal (as opposed to bicultural) political arrangements:

1. The value of tikanga [cultural values] - that is the need for a constitution to relate to or incorporate the core ideals and the 'ought to be' of living in Aotearoa.

2. The value of community - that is the need for a constitution to facilitate the fair representation and good relationships between all peoples.

3. The value of belonging - that is the need for a constitution to foster a sense of belonging for everyone in the community.

4. The value of place - that is the need for a constitution to promote relationships with, and ensure the protection of Papatūānuku [the Earth].

5. The value of balance - that is the need for a constitution to ensure respect for the authority of rangatiratanga and kāwanatanga within the different and relational spheres of influence. 
6. The value of conciliation - that is the need for a constitution to have an underlying jurisdictional base and a means of resolution to guarantee a conciliatory and consensual democracy.

7. The value of structure - that is the need for a constitution to have structural conventions that promote basic democratic ideals of fair representation, openness and transparency. (Matike Mai Aotearoa, 2016, p. 69)

He whakairo here whakaumu also showed the importance of relational justice:

Contest and debate were regarded [at the consultation meetings that informed the report] as essential to good decision-making but there was concern that unless it was placed upon some tikanga about how conflict or difference could be managed then any rangatiratanga and kawanatanga spheres of influence would have difficulty working together. (Matike Mai Aotearoa, 2016, p. 71)

The following points were considered important:

- Recognising and acknowledging the kawa and tikanga [culture and cultural practices] of each marae, hapū and iwi [meeting house, sub-tribe and tribe];

- Restoring, reclaiming and re-practicing our tikanga and kawa;

- Learning, teaching and transmission of Te Reo Māori [the Maori language];

- Retelling our own histories in our own ways;

- Learning and understanding how our tipuna [ancestors] lived before us;

- Understanding the roles of men and women, tuakana and teina [older and younger relatives of the same generation], and their importance in our societies;

- Ensuring that Te Ao Māori becomes a living reality for us as tangata whenua [people of the land]. (Matike Mai Aotearoa, 2016, p. 119)

These values could reasonably inform Maori citizenship and political voice.

Guaranteed Maori representation in parliament is an effective illustration of deliberative democracy's capacity to include an indigenous voice. It means that Maori contribute to the parliamentary check on the executive while also enjoying a greater likelihood of ministerial appointment and shows that New Zealand politics is distinguished by a differentiated liberal 
citizenship of significant potential. It is of much greater potential than contemporary Maori discussions about 'constitutional transformation' care to admit. Indeed, the indigenous right to participate fully if they so choose ... [in the] life of the state' (UN, 2007b, art. 5) is a right that biculturalism understates, and that He whakairo here whakaumu does not properly consider.

Guaranteed representation in parliaments is one of the ways in which political systems recognise difference. Such recognition allows for inclusion: when different people sit in the one parliament, their commonalities emerge from the respect that is implicit in the recognition of difference.

Guaranteed Maori representation in the New Zealand Parliament has occurred since 1867. Initially, the number of Maori seats was fixed at four. Since 1993, the number has been set in proportion to the number of Maori voters who choose to register on the Maori electoral roll. In 2019, there were seven Maori parliamentary seats. The social-democratic Labour Party won all seven of those seats at the 2017 general election. Maori citizens were also elected from general constituencies and party lists, providing additional Maori members of parliament from the Labour, National, New Zealand First, ACT and Green parties.

In Maori constituencies, Maori candidates are free to use their own culturally reasoned arguments to elicit support. Voters are free to evaluate alternative positions through a meaningful self-defined cultural prism, yet the UN special rapporteur's endorsement of New Zealand's liberal inclusivity has been conditional. While he welcomed 'New Zealand's efforts to secure Maori political participation at the national level' (UN, 2011, p. 20), he observed that:

these efforts should be strengthened, and the State should focus special attention on increasing Maori participation in local governance. The Government should consider reversing its decision to reject the findings of the Royal Commission on Auckland Governance and guarantee Maori seats on the Auckland City Council. (p. 20)

Local governments do not have to assure Maori representation, but they are required to 'establish and maintain processes to provide opportunities for Maori to contribute to the decision-making processes of the local authority' (Local Government Act 2002 [NZ], s. 81) 81). Vulnerability of this kind shows the importance of indigenous peoples asserting their 
positions as members of the nation-state. It is only in this way that the rights that indigenous peoples might enjoy in and over their own affairs can be protected.

\section{'Constitutional Recognition Must Make Indigenous Lives Better. Otherwise What's the Point?'1}

In 1996, the Canadian Royal Commission on Aboriginal Peoples recommended the creation of an aboriginal parliament. The recommendation followed the Native Council of Canada's proposal that a House of First Peoples should 'have the power to veto certain legislation put before it, or that passing such legislation require a double majority of the House of Commons and the House of First Peoples' (as cited in Boutilier, 2017, p. 14). The Canadian royal commission's remarks on the purpose of an aboriginal parliament is equally relevant to New Zealand:

The creation of an Aboriginal parliament would not be a substitute for self-government by Aboriginal nations. Rather it is an additional institution for enhancing the representation of Aboriginal peoples within Canadian federalism. (Royal Commission on Aboriginal Peoples, 1996 [Canada], p. 363)

In Australia, Axelby and Wanganeen (2017) proposed a number of political and institutional values to assure indigenous people's meaningful decision-making authority. They argued that political power can only come, in a substantive way, from the Australian Constitution (Axelby \& Wanganeen, 2017). Yet, as they acknowledged, and as this chapter has also argued, there is no absolute connection between the citizenship rights that constitutions recognise and the capacity for citizenship. Constitutions are grounded in law, but capacity is also grounded in politics, leading Axelby and Wanganeen to declare, in the title of their opinion piece, 'Constitutional recognition must make indigenous lives better. Otherwise what's the point?'.

Constitutional recognition must lead to political recognition — to assessing political questions of transformative potential and dealing with questions of how and on whose terms indigenous peoples belong to the modern state,

1 The title of Axelby and Wanganeen's (2017) opinion piece in The Guardian. 
such as: What political capacities ought to proceed from one's position as an indigenous citizen of the Commonwealth of Australia? What does 'the Commonwealth' mean for an indigenous person? While citizenship is the embodiment of the rights one holds by virtue of one's membership of a political community, it is the capacity to make something of those rights that creates the connection between citizenship and self-determination. Watson and Venne (2012) argued that the Declaration cannot contribute to establishing that connection. In their view, it is inadequate as an instrument of indigenous rights because its provisions do not counter the state's assimilationist tendencies. However, an alternative question for a transformative politics of indigeneity is whether the Declaration can assist with the reconfiguration of the state and its internal distributions of power.

Effective policy requires that the right questions are asked and the right problems identified. Policy paradigms that are successful for indigenous peoples (in Australia and elsewhere) are ones in which people may exercise the capacity for self-determination-that is, where they may enjoy the capacity to harness the powers and opportunities of citizenship for their own purposes. For example, Davis (2013) argued that, as the Australian Indigenous community-controlled health sector can reach individuals and families that no government could ever possibly reach' (p. 13), 'we cannot leave it to the state' (p. 13). Further:

The next phase does not require us to agonise over how the state is or is not implementing [the Declaration]; we need to take ownership of the text and we need to put meat on the bones of [the Declaration]. (p. 13)

Around 50 per cent of the Indigenous Australian population use Indigenous health services (Mazel, 2016). As discussed in Chapter 5, ACCHOs were established in response to the systematic exclusion of Indigenous peoples from health policymaking and the health system's sustained failure to provide Indigenous peoples with services of equivalent quality to those provided to other citizens (O'Sullivan, 2015). Their use by Indigenous people suggests the importance attached to cultural context in the provision of health services. ACCHOs give communities (as opposed to governments) the power to determine how health services are provided. However, self-determination requires stronger institutional arrangements for supporting community priorities in the allocation of resources. This suggests that there is a case, both morally and 
pragmatically, for an Indigenous entity to make funding decisions based on contestable bids from ACCHOs. An Indigenous-health purchasing agency was recommended to the government by the Health and Hospitals Reform Commission in 2009. It was thought that such an agency would provide strong institutional support to self-determination in health by giving Indigenous people self-determination over funding decisions and removing from debate the proposition that health systems have no obligation to take cultural imperatives and preferences into account in their treatment of Indigenous people (see O'Sullivan, 2015). However, the recommendation was not accepted.

The argument for an Indigenous-health purchasing agency is not necessarily, or only, about the redistribution of resources but also about the redistribution of authority. To put this another way, it is about an Indigenous share in the sovereign authority of the state that is strong enough to allow Indigenous people to set their own healthcare priorities. At present, ACCHOs operate in a context of 'dependent autonomy'. If Indigenous people do not take their place within the state, they cannot avoid dependence, for it is the state that determines the political and legislative context in which people exercise their capacities as citizens. It is the state that appropriates public money to the indigenous shadow state.

As Mazel (2016) observed, governments have come and gone since 1971, but $\mathrm{ACCHOs} \mathrm{have} \mathrm{stood} \mathrm{firm} \mathrm{as} \mathrm{examples} \mathrm{of} \mathrm{what} \mathrm{self-determination}$ really looks like-they have remained. Rowse (2000) described them as the most important contemporary expression of self-determination because the politics of Indigenous citizenship is a struggle not only over notions of right but also about ways of being present and effective, that is, about capacities for Indigenous participation' (p. 86).

Inequities in policy outcomes transcend the unfortunate to raise important questions of justice. Daniels (2008) asked, 'Why should some people be at such a health disadvantage through no fault of their own, losers in a natural and social lottery assigning them from birth to an unhealthy place?' (pp. 109-110). For indigenous people, health inequities are the outcome of unjust terms of association. If indigenous people 'are justified in claiming a right to health care only if it is derivable from an acceptable general theory of distributive justice' (Daniels, 1979, p. 174), then that theory must be concerned with the distribution of political authority at least as much as it is concerned with the distribution of material resources. The questions of how, by whom and for whom decisions are made are 
important, as health outcomes tend 'to be a good guide to the underlying capabilities' (Sen, 2004, p. 23) that people enjoy. Health outcomes are a reflection of political capacity and of people's capacity as citizens.

The internationally sanctioned right to health is only progressively realisable (UN, 1966b, pt. II art. 2[1]). Jurisdictions such as Australia, Canada, New Zealand, Norway and the US have the capacity to address a policy problem that affects small percentages of the national populations and for which there are innumerable examples of policy success (O'Sullivan, 2015). Political decisions cannot remove the injustice of colonialism, but they can tend towards the creation of noncolonial relations for the present and future.

In 2016, the Australian Medical Association's annual report card on Aboriginal and Torres Strait Islander health considered the relationship between 'political will' and health outcomes, and explored measures to reduce the incidence of rheumatic heart disease among Indigenous Australians. The association asked:

what medicine is required to prevent new cases of RHD [rheumatic heart disease]? Awareness and political will. For the former, there is growing public awareness about the terrible impact of RHD in Indigenous communities ... In relation to political will, the AMA [Australian Medical Association] makes a Call to Action to prevent new cases of RHD in Indigenous Australia by 2031. This is also the target year of the Council of Australian Governments (COAG) Closing the Gap Framework objective to improve the life expectancy of Indigenous Australians. Preventing new cases of RHD in Indigenous Australia by 2031 will make an important and necessary contribution to the achievement of this overarching life expectancy target. (AMA, 2016, p. 3)

There is a relationship between political will and more explicit state acceptance of the Declaration. Ornelas (2014) proposed the creation of agencies within state bureaucracies to oversee and coordinate the Declaration's implementation. Such agencies would not only signal the Declaration's desirability but also that states are willing to submit to international oversight; however, this is unlikely given the absence of political will in most states.

Nevertheless, it is worth defending a process of 'collective deliberation conducted rationally and fairly among free and equal individuals' (Benhabib, 1996, p. 69). The presumption that internal self-determination 
is less valuable than secession is valid only if the two are equally realistic possibilities and therefore comparable. When internal decolonisation is the only pragmatic possibility, it is more politically advantageous to examine the potential that exists within that context rather than to dwell on secession's hypothetically greater political value.

Contemporary postsettler states sometimes 'overtly reject and undermine indigenous social and political orders' (Champagne, 2013, p. 14), and sometimes they do not. Further, the extent to which they are willing to entertain those orders as ones of national political significance vary. Willingness is subject to significant change according to shifting domestic political values and to governments' perceptions of what they need to do to maintain broader electoral support. From an assimilationist perspective, there is a rhetorical attractiveness in the view that self-determination creates a 'tension between the democratic principle of majority rule and the disruptive potential of minority separatism' (Schulte-Tenckhoff, 2012 , p. 81). However, the tension is overstated. The 'separation' of indigenous peoples from the nation-state imposes no restriction on the liberal political rights of other citizens.

Citizenship of the nation-state is not something to be undervalued. It is not necessarily assimilationist, and citizenship of an indigenous nation does not need to be traded off to hold meaningful state citizenship. Indigenous resistance to citizenship tends to focus on specific curtailments of the right to exist as indigenous, not the existence of the state per se. However, if the state is to avoid functioning as a neo-colonial entity, indigenous peoples must contribute to the shaping of its institutions and opportunities to participate at every level of its decision-making processes. In this way, citizenship becomes the embodiment of a set of political capacities, and the ways in which these are constrained and in which they may be exercised are important.

It is significant that in Canada, as in New Zealand, treaty rights extend to the urban diaspora (Belanger, 2010). However, if there is a duty 'to seek out urban Aboriginal leaders for their participation' (p. 14), then there is an assumption that arrangements are not already in place for aboriginal people to participate as a matter of course, even though the 'honour of the Crown' (Haida Nation, 2004, paras. 16-19) demands consultation and the accommodation of indigenous rights where this is found to be just. In 2014, the UN special rapporteur observed that consultation processes in Canada were 'generally inadequate' and that: 
There appears to be a lack of a consistent framework or policy for the implementation of this duty to consult, which is contributing to an atmosphere of contentiousness and mistrust that is conducive neither to beneficial economic development or social peace. (UN, 2014, p. 18)

Greater participation would assure an indigenous presence and capacity to propose new legislation.

Overall, Canada has a strong legislative and jurisprudential framework for addressing the indigenous right to self-determination. For its part, the TRC imagined the Declaration as having a significant role in domestic politics. However, indigenous people commonly lack the financial capacity to make governance arrangements work. There is also a tension in the sphere of indigenous land rights, such that Aboriginal title is often 'regarded as a burden on the Crown's sovereignty' (Schulte-Tenckhoff, 2012, p. 66). Yet self-determination can be conceptualised as a burden on Crown sovereignty only if that sovereignty is understood as existing in its own right and not proceeding from the collective sovereignty of the people. If sovereignty inheres in all and not just some of the people, there ought to be no conflict. Political tension emerges on this point because of the nature of indigenous belonging and because the nature of the share in political authority that belongs to them is unsettled.

\section{Marginalising Citizenship or Indigenising the Bureaucracy?}

Marginalisation through denial is a common state strategy of containment, even though the ongoing effects of residential schools in Canada and the stolen generations in Australia continue to explain social dysfunction and diminish people's capacities for meaningful citizenship. The Australian Indigenous Doctors' Association (2010) argued that:

The policies of assimilation, elimination, forced child removal, protection and segregation that were imposed after colonisation resulted in a huge disruption of traditional social institutions and kinship ties. The damage to the intricate kinship systems and community cohesion of Aboriginal people through the stolen generations cannot be overemphasised. (p. 7) 
The human right to be part of a family ought to be sacrosanct and precede the assimilationist intent of a state. In Australia, the denial of that right is hugely ironic when considered alongside the Howard Government's (1996-2007) privileging of family as the only legitimate subnational unit of identity, especially as that government's policy rhetoric was not supported by measures to rebuild those families rendered dysfunctional by state-sanctioned violence. Similarly, a politics of exclusion distinguishes the Indigenous Australian journalist Stan Grant's (2016) discussion of his grandfather's 'personal journey in the black migration from mission to town a distance of mere miles, but an epochal trek' (para. 2). Grant's grandfather's journey was meant to be a migration of opportunity; however, three generations later, that opportunity remains unobtainable for many Indigenous peoples. Describing an isolation and alienation that many Indigenous peoples face, Grant observed that 'we lived in Australia and Australia was for other people' (A cage in search of a bird, para. 3). His observation is reflected in Indigenous people's perceptions of public institutions, hospitals, schools, courts and, especially, parliaments, as being for other people. However, Grant (2016) also challenged the distinction that the anthropologist WEH Stanner made between the Indigenous and non-Indigenous to create a rigid binary world:

Stanner once remarked that for Indigenous people the dreaming and the market are mutually exclusive. For Stanner ... Indigenous people were fixed in time and place. (Redefining aboriginality, para. 3)

The market was elsewhere.

Referring to Australia as a 'parallel' society, Grant identified a different binary, one in which the number of Indigenous students completing secondary school was increasing markedly, while policy failures in health, criminal justice, housing, employment and economic development for Indigenous people continued, showing that 'life in the open society ... can be lonely [and] alienating' for Indigenous Australians ('Leaving the shadow world', para. 4). Yet it need not be: through a process of indigenising the bureaucracy - that is, by allowing Indigenous aspirations and epistemologies to influence policymaking in secure and meaningful ways-life in the open society could be inclusive and respectful. This could be achieved in New Zealand by bringing the cultural values set out in He whakairo here whakaumu into public relationships, and in Canada by complementing and facilitating nation-to-nation policy cocreation. 
In Canada, the National Indigenous Economic Development Board's 'hope for the future' rests on differentiated liberal citizenship:

The massive expansion of Indigenous businesses, increased shared governance, the intersection of indigenous knowledge and science, the enhanced interest from the Federal and provincial governments and reconciliation, and especially the passion, dedication and intelligence of First Nations' children and youth. (Public Policy Forum, 2017, p. 10)

In 2012, the Harper Government's (2006-2015) special federal representative on West Coast energy infrastructure was commissioned 'to identify approaches that could meet Canada's goals of expanding energy markets and ensuring Aboriginal participation in the economy' (Eyford, 2013 , p. 2). The resulting report, which emphasised trust, inclusion and reconciliation, represented a significant departure from prevailing indigenous policy. Significantly, it stressed 'reconciling interests' rather than differences (Eyford, 2013), presumed that indigenous peoples comprised a legitimate part of the public and argued that resource development ought to serve their interests. To this end, the report recommended that:

- Canada and Aboriginal communities need to build effective relationships and this is best achieved through sustained engagement;

- Aboriginal communities view natural resource development as linked to a broader reconciliation agenda;

- Aboriginal communities will consider supporting natural resource development if it is undertaken in an environmentally sustainable manner; and

- these projects would contribute to improving the socio-economic conditions of Aboriginal communities. (Eyford, 2013, p. 1)

The subject of the report was economically important to the government. Since energy exports require developing pipelines and shipping terminals on indigenous lands, the government's aspirations could not be pursued without considering constitutionally protected indigenous rights.

While 'equality in the process of public deliberation may well be intrinsically just' (Christiano, 1997, p. 244), the question of how political systems and institutions protect equality is distinguished by 
important differences of perspective between state and indigenous actors. An important difference of perspective is evident in the situation described by Belanger (2010) wherein:

Canadian officials consider Aboriginal self-government a policy issue [and] Aboriginal leaders consider self-determination a complex set of relationships that incorporate provisions protecting historic lands, as well as a continued political interface respecting historic treaties. (p. 6).

Policy contradictions leave indigenous people unable to make longterm decisions with certainty and clarity, and ill-equipped to maximise the inherent economic advantages that transgenerational investment timeframes provide to their commercial entities.

Policy tensions also exist between the Canadian Government and First Nations over the status of health care as a treaty right. The issue rests on whether health care is a right in distributive justice or a right of indigeneity. The distinction has implications for how and by whom decisions are made and for which purposes. From a purely distributive perspective, it may be sufficient for the state to make decisions on its own after consultation. However, a politics of indigeneity would require substantive indigenous participation and help to address the philosophical questions set out by the UN special rapporteur in 2014, which also described the political context in which Trudeau came to office in 2015:

The relationship of Canada with the indigenous peoples within its borders is governed by a well-developed legal framework and a number of policy initiatives that in many respects are protective of indigenous peoples' rights. But despite positive steps, daunting challenges remain. The numerous initiatives that have been taken at the federal and provincial/territorial levels to address the problems faced by indigenous peoples have been insufficient. The well-being gap between aboriginal and non-aboriginal people in Canada has not narrowed over the past several years; treaty and aboriginal claims remain persistently unresolved; indigenous women and girls remain vulnerable to abuse; and overall there appear to be high levels of distrust among indigenous peoples towards the government at both the federal and provincial levels. (UN, 2014, p. 1) 
Canada was engaged in a process of negotiating new treaties with indigenous peoples. According to the special rapporteur, 'at least in the conception', these served as examples of 'good practices' in the realisation of indigenous human rights (UN, 2014, p. 6). However, the relationship between indigenous peoples and the state remained 'strained'. The special rapporteur found it 'difficult to reconcile Canada's well-developed legal framework and general prosperity with the human rights problems faced by indigenous peoples in Canada, which have reached crisis proportions in many respects' (p. 6).

The Declaration presumes that self-determination requires an active indigenous citizenship. It also presumes that the state can be indigenised. Therefore, attention must be paid to group rights and interests so that politics can attend to the common good, which 'cannot be realised as the aggregate outcome of individuals pursuing their private interests' (Elster, 1997, p. 14). For these reasons, the common good may not, in fact, be a commonly understood aspiration. People define commonality from their own vantage points, conditioned by different life experiences and aspirations that are mediated through culture and, for indigenous peoples, conditioned by colonialism itself. As Rawls (1971) proposed:

Justice as fairness begins with the idea that where common principles are necessary and to everyone's advantage, they are to be worked out from the viewpoint of the suitably defined initial situation of equality in which each person is fairly represented. The principal of participation transfers this notion from the original position to the constitution ... [thus] preserv[ing] the equal representation of the original position to the degree that this is feasible. (pp. 221-222)

There must be equal political capacity to work out a shared conception of the 'common'; yet the idea of a completely virtuous citizen is naive. Indigenous peoples' exclusion from substantive citizenship well illustrates the point, as 'normative consensus ... has [not] been secured in advance through tradition and ethos' (Habermas, 1997, p. 245). How, then, do indigenous peoples find political voice in a system whose institutions are not structured to achieve political equality, especially because, in practical terms, there is no original position of equality?

The question is also one of how to reach points of equality without compromising indigenous distinctiveness. How might distinctiveness be reflected in political institutions? Political decision-making is not neutral. 
Its biases must be open to scrutiny, not just from those with different biases, but also from those with fundamentally different views of the common good mediated by culture and colonial experience. Is it possible that 'sovereignty should express itself only under the discursive conditions of an internally differentiated process of opinion and will formation' (Habermas, 1997, p. 46)?

There must be accepted tests of reasonableness and procedures for removing unreasonableness from public decision-making. Indigenous voice depends on the acceptability of a plurality of reasons.

People's perspectives change through exposure to others' ideas. Reasoned deliberation requires that all who deliberate are, as a matter of course, exposed to indigenous ideas. Public reason consequently requires that all people are equally part of the 'public':

to the extent that public deliberation calls upon a set of morally important qualities, such as rationality, autonomy and respect for others, there is some reason to think that these traits, which are important in politics, will be promoted more in a society that encourages deliberation among all of its citizens. (Christiano, 1997, pp. 248-249)

It may be idealistic, but it is still aspirationally important to consider that:

If discussion is not in an egalitarian context, then many more points of view will have to be debated to the extent that previously neglected sections of society come to the fore

we ought not be aiming at political consensus on moral and political matters. As long as public discussion acts as a process of trial and error for excluding forms of ignorance, it serves a useful purpose. (Christiano, 1997, pp. 248-250)

The point at which political agreement matters most is a procedural one and involves the steps that will be followed to make decisions and their underlying rationale.

Deliberation requires citizens to engage respectfully with one another and with concern for the common good; it is a 'condition of political justification' and 'outcomes are justified because they are brought about in certain ways' (Christiano, 1997, p. 246). Such deliberation strengthens 
democracy for indigenous peoples because it is 'able to root out policies based on unsubstantiated prejudices' (Christiano, 1997, p. 247). Ultimately, equal participation in discussion and debate depend on supporting institutional arrangements.

\section{Conclusion}

The Declaration affirms an indigenous people's right to separate itself from the colonial society established over its territories. An indigenous people need not presume equal citizenship of the colonial state or concern itself with the affairs of the state other than through a nation-to-nation relationship. For example, it may adopt a kind of bicultural binary to justify an independent-though isolationist-self-determination as He whakairo here whakaumu proposes for New Zealand. However, this is a limited and constraining approach to politics, as it overlooks the political value of claiming a share in public sovereignty.

In contrast, differentiated liberal citizenship recognises sovereignty's dispersed character and presumes substantive indigenous voice as a right of citizenship belonging to indigenous persons as much as to anyone else. It is reasonable that arrangements are made for that voice to be expressed in ways that demonstrate participatory parity.

Self-determination is a relative and relational power that the Declaration allows indigenous peoples to exercise within the state as liberal citizens and beyond the state as members of indigenous nations. The close relationships between these two spheres of political authority means that the capacity for self-determination is maximised by a politics that is equally attentive to both. 
This text is taken from 'We Are All Here to Stay': Citizenship, Sovereignty and the UN Declaration on the Rights of Indigenous Peoples, by Dominic O'Sullivan, published 2020 by ANU Press, The Australian National University, Canberra, Australia.

doi.org/10.22459/WAAHTS.2020.09 